\title{
M useu e memória biográfica: um estudo da Casa de Cora Coralina
}

\author{
Andréa Ferreira Delgado*
}

\begin{abstract}
R esumo: A disputa pela fabricação da biografia de Cora Coralina envolve uma rede de memórias que se apóiam, se cruzam ou se excluem: a autobiografia tecida pela poeta; a memória biográfica produzida pelo Museu Casa de Cora Coralina; a biografia escrita pela fillha, Vicência Brêtas Tahan; a memória subterrânea engendrada na cidade de Goiás. Nesse campo de conflitos, pretendo investigar o trabalho de construção e gestão da memória promovido pelo discurso museológico biográfico. No museu Casa de Cora Coralina, a disposição, o contexto e a configuração espaço-temporal dos móveis, dbjetos, fotografias e poesias constroem a biografia da poeta em simbiose com a memória da cidade e representam o projeto de promover sua imortalização como Mulher-Monumento de Goiás.
\end{abstract}

Palavras-chave: museu; memória; gênero.

Em 2001, a cidade de Goiás recebeu o título de Patrimônio da Humanidade, ao passar a integrar a sel eta Lista do Patrimônio M undial, el aborada pela O rganização das $\mathrm{N}$ ações U nidas para a E ducação, Ciência e Cultura (Unesco). Este é o mais recente episódio de uma trama que instituiu Goiás como cidade histórica e turística. N esse campo da memória, Cora Coralina é personagem principal: 0 processo de monumentalização da poeta como símbolo emblemático da cidade de Goiás constituiu peça estratégica na construção desse "Iugar da memória" (Nora, 1993).

A disputa pela fabricação da biografia da Mulher-M onumento envolve uma rede de memórias que ora se apóiam ou se cruzam, ora se excluem: a autobiografia tecida pela poeta; a memória biográfica produzida pel o museu Casa de Cora Coralina; a biografia escrita pela filha,

\footnotetext{
* Doutora em História pela Universidade Estadual de Campinas e professora do Centro de Ensino e Pesquisa A plicada à Educação (Cepae), da Universidade Federal de Goiás. Email: andreadelgado@uol.com.br.
}

Vicência B rêtas Tahan; a memória subterrânea engendrada na cidade de Goiás (Delgado, 2003).

Esse artigo pretende delinear essa intriga com base na investigação do trabalho de construção e gestão da memória promovido pelo discurso museológico biográfico da Casa de Cora Coral ina, local mais visitado pel os turistas na cidade de Goiás. Nosso foco de análise compreende desde a sua inauguração, em 1989, até o final de 2001, quando uma grande enchente fez com que o Rio Vermelho transbordasse e inundasse a Casa Velha da Ponte, causando grandes estragos ao acervo. Depois de seis meses de reformas, nos quais o museu continuou parcialmente aberto à visitação, ocorreu a sua reinauguração, com al terações na composição da exposição decorrentes do agenciamento de outras concepções de museologia.

L ogo após o falecimento da poeta, ocorrido em abril de 1985, um pequeno grupo de moradores de Goiás começou a organizar a A ssociação Casa de Cora Coralina, com o objetivo imediato de lutar pela preservação da Casa Velha da Ponte, herdada pelos filhos da 
poeta, que manifestavam o desejo de vender 0 imóvel. Na ata da assembléia de fundação da Casa de Cora Coralina, realizada no dia 28 de setembro de 1985, justifica-se a criação da entidade pela "necessidade da realização de um trabalho sério, visando à preservação dos bens imóveis e móveis, assim como dar prosseguimento à concretização dos ideais da nossa mai or poetisa" (L ivro de A ta da Casa de Cora Coralina, p. 1). Nos estatutos aprovados nessa ocasião, constam como finalidades da Casa de Cora Coralina:

projetar, executar, colaborar e incentivar atividades culturais, artísticas, educacionais e filantrópicas visando sobretudo à valorização da identidade sociocultural do povo goiano, bem como preservar a memória e divulgar a obra de Cora Coralina. (C apítulo I, art. 2. Livro de A ta da Casa de Cora Coralina, p. 5, grifos meus)

A rticula-se, assim, o trabal ho de gestão da memória de Cora Coralina com o a promoção do conjunto de valores culturais que pretendem delinear a identidade do povo goiano. Tomando a goianidade como pressuposto, a criação dessa entidade revela-se peça estratégica não apenas no processo de monumentalização de Cora Coralina, mas na construção simbólica (Ortiz, 1985) da identidade regional. A produção de indivíduos-monumento (A breu, 1994) revela-se, portanto, como um importante mecanismo de constituição da memória coletiva na sociedade contemporânea.

$\mathrm{N}$ a primeira assembléia da A ssociação Casa de Cora Coralina foi el eita a primeira diretoria, de "caráter provisório com mandato de sessenta dias": presidente - M arlene Gomes de Velasco; vice-presidente - Idelmar de Paiva Neto e secretária - Salma Saddi de Paiva. Conforme as atas das assembléias da instituição, desde 1985 até 2003, repetiu-se essa composição da diretoria.

Efetivamente, a direção e a representação da instituição estão centralizadas pela "guardiã da memória" (Gomes, 1997) de Cora Coralina, a professora de literatura M arlene Vellasco, pessoa fundamental na trama da memória biográfica da poeta: a convivência com Cora uma "vivência cotidiana", ela afirma, de "comunhão permanente de idéias e convívio íntimo desde a infância" (Vellasco, 1999, p. 1) - e a elaboração de uma dissertação de mestrado a respeito da obra poética de Cora Coralina conferem autoridade ao seu discurso. No exercício de suas tarefas, Vellasco é constantemente assediada para reconstruir suas lembranças e as trabal ha constantemente, repetindo de forma incansável e incessante determinados episódios que compõem uma versão solidificada (Pollak, 1992) da poeta e reforçando determinados marcos de interpretação da vida e da obra que estabel ecem determinados contornos para a M ulher-M onumento.

A primeira ação da associação foi viabilizar a compra da Casa Velha da Ponte. A aquisição foi efetuada pela Prefeitura M unicipal de Goiás, com recursos da Fundação Nacional PróM emória e da Construtora A Icindo Vieira, de Belo Horizonte. Em 1988, após as obras de restauração, coordenadas pelo I nstituto do Patrimônio Histórico e A rtístico $\mathrm{N}$ acional (I phan), o imóvel foi doado à A ssociação Casa de Cora Coralina, entidade mantenedora do museu desde a sua inauguração, que ocorreu no dia 20 de agosto de 1989, durante as comemorações do centenário do nascimento de Cora Coralina.

Historiar os dezesseis anos de funcionamento do museu ultrapassa os limites destetexto, cujo objetivo é refletir sobre os significados da transformação da Casa Velha da Ponte em "casa da memória" (A breu, 1996), onde interagem aspectos materiais, simbólicos e funcionais para "parar o tempo, bloquear o trabalho do esquecimento, fixar um estado de coisas, imortalizar a morte, materializar o imaterial para prender o máximo de sentidos num mínimo de sinais" (Nora, 1993, p. 22), reinventando constantemente a $\mathrm{M}$ ul her-M onumento como patrimônio da cidade de Goiás.

No G uia dos imóveis tombados em G oiás, de autoria do arquiteto Gustavo Coel ho, a Casa Velha da Ponte é descrita como representante do "modelo típico da arquitetura residencial" do período colonial e a data da construção é apontada como anterior a 1782, correspondendo a uma das primeiras casas edificadas na $V$ ila $B$ oa de Goiás. 0 imóvel não é tombado individualmente, mas faz parte do conjunto arquitetônico e urbanístico incorporado ao Patrimônio N acional, pela ação do I phan, em 1978. 0 autor 
justifica o destaque da "C asa de Cora Coralina" no seu inventário, "pela importância sociocultural que representa no contexto da cidade, como residência de sua poeta maior" (Coelho, 1999, p. 67-68).

M ais do que pelo valor histórico, é como residência da $M$ ulher-M onumento que a Casa Velha da Ponte é singularizada no conjunto do patrimônio instituído pelo I phan. No entanto, 0 amál gama entre a poeta e a casa é muito mais complexo, pois constitui um dos mecanismos fundamentais do processo de monumentalização: Cora Coralina converteu a Casa Velha da Ponte em templo da memória autobiográfica, familiar e coletiva.

Quando vol tou para G oiás, em 1956, depois de 45 anos de ausência, ela abriu as portas da Casa Velha da Ponte para vender seus doces e conversar com os visitantes, transformando sua casa em um dos pontos turísticos mais procurados da cidade. A os visitantes, ela contava "estórias" de tesouros, fantasmas e poderes milagrosos da biquinha d'água localizada no porão.

No porão da casa de Cora Coralina tem um tesouro enterrado. Onde, ninguém sabe. "Quem quiser procurá-lo, pode" diz ela. "Se achar al guma coisa, dividiremos meio a meio". Esse tesouro vem sendo procurado há uns dois séculos. Cora conta a sua história para as visitas mais curiosas, a mesma história (ou estória, como ela gosta de grafar). [...] N o porão, entretanto, tem a famosa biquinha, de uma água que vem detrás da I greja do Rosário, um lugar chamado M orrinho, pelo povo. A biquinha foi construída no séc. XV III eacredita-se que quem bebe de sua água, na própria mão, se livra dos azares por muito tempo. (Cinco de Março, Goiânia, 4 a 10 de fevereiro de 1974)

Quatro fantasmas guardam um tesouro que estaria escondido nal gum canto dos porões da casa onde reside a escritora Cora Coralina, na Cidade de Goiás. Os fantasmas, segundo afirmação da escritora, só deixarão o porão no dia em que o tesouro for achado, comunicação que Ihe foi feita pelos entes desencarnados: "São fantasmas familiares que não me amedrontam, apesar de que, às vezes, provocam algum incômodo fazendo barulho e dando pancadas nas tábuas do assoalho", comenta Cora Coralina. A escritora vilaboense garante que os quatro fantasmas nada têm a ver com as suas histórias e fantasias. Ela sabe que eles estão no seu porão e diz que, por mais de uma vez, fez contatos com eles: "não me preocupo se as pessoas acreditam ou não nesse fato. Eu os vejo e falo com eles. Por certo outras pessoas, também, poderão vê-los, e o fato fica no julgamento de cada um" (D iário da M anhã, Goiânia, 7 a 13 de abril de 1975, grifos no original )

Essas e outras histórias são narradas em detalhes pela escritora nos livros Estórias da Casa Velha da Ponte (1986) e 0 tesouro da Casa Velha (1996). Ao longo da obra de Cora Coralina, a escrita da memória tece a rede de significados que investe os espaços da Casa Velha da Ponte de espessura temporal, convertendo-a em um lugar singular, lendário e mítico.

\section{CASA VELHA DA PONTE [...]}

Olho e vejo tua ancianidade vigorosa e sã.

R evejo teu corpo patinado pel o tempo, marcado das escaras da velhice, desde quando ficaste assim? [...]

MINHA CASA VELHA DA PONTE [...] assim a vejo e conto, sem datas e sem assentos. A ssim a conheci e canto com minhas pobres letras. Desde sempre. [...]

\section{CASA VELHA DA PONTE}

Velho documentário de passados tempos, vertente viva de estórias e de lendas.

M inha bisavó falava de seus antigos ancestrais. [...]

Estórias, fantasias de "enterro do ouro", muito ouro que se pesava às arrobas, [...] e assim se criou a mística do "enterro do ouro" na Casa Velha da Ponte.

Nestacasa mecriei emefiz jovem. M eus anseios extravasaram a velha casa. A rrombaram portas e janelas, e eu me fiz ao largo da vida. Pobre, vestida de cabelos brancos, voltei à CASA VELHA DA PONTE, barco centenário encaIhado no Rio Vermelho. [...]

CASA VELHA DA PONTE, és para o meu cântico ancestral uma benção madrinha do passado. (Coralina, 1986, p. 7-11)

Seja por meio da produção literária, seja através de reportagens veiculadas em jornais, revistas e emissoras de televisão, a Casa Velha da Ponte foi associada a Cora Coralina e viceversa. $\mathrm{N}$ a rede discursiva que monumentaliza a poeta, essa simbiose testemunha a ligação da ilustre moradora com o passado imemorial configurado na cidade colonial. 
0 discurso daqueles que dirigiram a transfiguração da casa em museu produz a idéia que a exposição museológica eterniza a poeta ao representar a continuidade do cotidiano doméstico:

Tudo continua como no tempo de Cora, só que, agora, transformada em museu, a C asa ganhou ares de administração, com funcionários e tudo bem distribuído, para os ol hos atentos e curiosos dos turistas. 0 importante é que a presença de Cora está viva, em cada canto da casa. (Telles, 1991, p. 34)

Os espaços da Casa Velha da Ponte estão impregnados da presença de Cora Coralina, os significados se entrelaçam. As pessoas continuam procurando a Casa Velha, buscando ali Cora Coralina que, de certa forma, nos seus objetos, nos seus espaços, mantém-se presente. (F older "Casa Velha da Ponte". Fundação Pró-Tur Cidade de Goiás, 1998)

0 museu é instituído como um espaço situado fora do tempo, capaz de capturar vários recortes do passado, tornando-os imunes à corrosão da passagem do tempo e conservandoos em um presente eterno. A ssim como os lugares "heterotópicos" designados por Foucault (1994), o museu Casa de Cora Coralina configura um projeto de organização e acumulação detodos os tempos da vida da poeta, constituindo um arquivo geral de objetos, imagens e discursos presentificados para evocar Cora e promover sua imortalização.

0 trabal ho de produção e gestão da memória é omitido pelo discurso que propõe o resgate da essência de uma história de vida por meio de uma exposição auto-significante e auto-explicativa. No entanto, a organização do acervo resul ta do projeto museológico de Célia Corsino eV irgínia Papaiz, que foi el aborado e executado para atender às expectativas da associação mantenedora do museu. Portanto, a narrativa material da Casa de Cora Coralina é fruto de uma sel eção material e simbólica, cujo interesse não é reproduzir "tudo como no tempo de Cora", mas enquadrar o passado dentro dos limites da biografia que se quer fabricar e oficializar.

$\mathrm{N}$ a montagem da exposição museológica, determinados objetos, imagens e discursos são escol hidos como documentos biográficos, cujo conjunto pretende delinear e perpetuar a memória de Cora Coralina. Em contrapartida, outros tantos objetos, imagens e discursos são descartados, ocultados, silenciados, em um trabal ho de produção do esquecimento. A final, - M onumento precisa ser constantemente esculpido, divulgado e protegido das interpretações que questionam a exemplaridade da poeta como artesã e guardiã da memória coletiva.

$M$ ais do que celebrar o passado, a instituição trabal ha 0 presente ao empenhar-se na visibilização simbólica da M ulher-M onumento por meio de uma série de eventos que marcam o calendário da cidade histórica que se volta para o turismo. Como lugar da memória, o museu exerce a "vigilância comemorativa" necessária para estabelecer, manter e reinventar o culto a Cora Coralina por meio das comemorações anuais associadas às datas biográficas. Nesses rituais, reproduzem-se os marcos discursivos estabelecidos pela própria Cora Coralina, tornando-a artífice não apenas da invenção de si mesma pela prática autobiográfica, mas também da sua posteridade.

0 museu também promove eventos artísticos, incentivando e divulgando a literatura, a música, as artes plásticas, o teatro e 0 artesanato goianos. Com as cerimônias de celebração da memória da poeta e de afirmação da goianidade, a Casa de Cora Coralina (re)produz continuamente os eixos da monumentalização ao agenciar a criação de novos discursos textuais e iconográficos que, por meio de múltiplas estratégias, reafirmam a biografia oficial ea simbiose com a cidade de Goiás.

\section{A liturgia e a exposição museológica da Casa de Cora Coralina}

Vamos voltar nossa atenção para o interior da Casa Velha da Ponte, buscando elementos para desvelar os mecanismos de construção da narrativa material que produz a memória biográfica. Na exposição museológica, "tudo conta, tudo simboliza, tudo significa", configurando 0 lugar da memória como "fechado sobre si mesmo, fechado sobre sua identidade e recol hido sobre seu nome" (Nora, 1993, p. 27). Em outras palavras, é na investigação das práticas museológicas que devemos buscar as estratégias de produção da biografia oficial. 
No "Corredor de Entrada" da Casa de Cora Coralina, além dos dois quadros com cartazes, produzidos por empresas que homenagearam a poeta, nos quais se destacam grandes retratos, quatro painéis introduzem o visitante no templo da memória:

A casa tinha sido de grande pompa. Os antepassados tiveram mineração e escravos na batéia sob vigilância implacável de feitores. 0 ouro das lavras chegava cada Sábado em cargueiros, trazidos em surrões de couro.

$\mathrm{Na}$ sala da frente, de janelas fechadas para a rua e abertas sobre o rio, fazia-se a medição e o peso.

Entregava-se na Casa da Real Fundição, pagava-se 0 quinto del Rei e dava-se a tara. Recebia-se em barras equivalentes com 0 carimbo legal, mais fáceis de serem guardadas. Trocava-se parte por cruzados para os gastos triviais.

Quando me entendi por gente, esse ouro achava-se evaporado, apesar de seu peso e quantidade, e a grandeza da casa acabara-se com os antigos donos.

Cora Coralina

M inha bisavó falava de seus antigos ancestrais.

0 primeiro lembrado de outro bisavó, um certo Thebas Ruiz, recebedor dos quintos reais, antes de morrer enterrou no porão da casa ouro avultado, grossas barras e mais lavrados. [...] Depois veio um Sargento-mor, bisavô de muitos, português colonial. U m Cônego Couto, liberal e dono de moedas, montes de ouro prataria. [...] U m capitão da guarda nacional, que diagonou milhares de homens felizes e analfabetos, capitães, majores e coronéis, enfeitados com galões dourados e vitalícios sem percal ços de reforma. U m desembargador da M onarquia - meu pai -, minha mãe viúva. $M$ inhas irmãs, eu, afinal a última sobrevivente de gerações passadas.

Cora Coralina

"Vivíamos na casa, minha mãe, minha bisavó, Eu, minha três irmãs e a cozinhei ra Lizarda". "M inha mãe, muito viúva, isolava-se no seu mundo de frustrações".

"Valeu muito minha mãe madrinha de carregar: Mãe Didi"

"M inha irmã mais vel ha governava. Regrava". "Duas criaturas me deram seus carinhos: minha bisavó e minha Tia N horita."
"U m dia, houve.

Eu era jovem, cheia de sonhos

Rica de imensa pobreza

que me limitava

entre oito mul heres que me governavam.

E eu partir em busca do meu destino".

CoraCoralina

A criação literária ressignifica a casa, anunciando para o visitante que, na perenidade do espaço, está inscrita a possi bilidade de encontrar o passado no presente. Esse conjunto de excertos reproduz 0 amálgama entre memorialismo e autobiografia, principal característica da obra de Cora Coralina: ao mesmo tempo, momentos de construção de uma memória autobiográfica e uma forma específica de criação da memória coletiva. A escriba apresenta a Casa Velha da Ponte como monumento da cidade, cujos alicerces remontam ao tempo mítico da exploração do ouro, ea si mesma como "última sobrevivente de gerações passadas", depositária da memória familiar que reconstrói a trajetória dos antepassados ilustres. A casa também emerge como centro das reminiscências autobiográficas, e a poeta vai esboçando um auto-retrato à medida que revela os personagens do seu universo familiar.

Esse conjunto de painéis, tal como os outros que estão presentes em todos os aposentos, demonstra a apropriação da literatura para a composição de um discurso museológico específico. Cora Coral ina criou enredos que entreteceram a casa com a cidade, com a história dos antepassados e com a própria vida, construindo múltiplos passados interligados. M usealizada, essa escrita da memória adquire novos significados. A museóloga, ao selecionar os excertos e escolher a localização de cada painel, combinando-o com os outros elementos da coleção, produz possibilidades polissêmicas de leitura.

A o longo da exposição, os painéis exercem papel fundamental na atribuição de sentidos e valores aos objetos e ao conjunto do espaço do museu, visto que são utilizados para caracterizar 0 atributo biográfico dos objetos e também para circunscrever os ambientes reconstituídos no museu ao universo doméstico vivenciado por Cora Coralina em diferentes momentos de sua vida. 
No final do "Corredor de Entrada", uma porta mantida sempre aberta dá acesso à "Varanda", local de recepção dos visitantes e também uma das salas de exposição do museu. A recepcionista informa o preço do ingresso e orienta o visitante para esperar o guia que vai acompanhá-lo na visita.

Penetrar nesse universo museológico exige a construção de um texto que permita ao leitor o contato com a configuração espaço-temporal do discurso visual da exposição. Para nos aproximar da memória biográfica instituída pela narrativa museológica, produzi seqüências iconográficas de cada um dos aposentos e as organizei, acompanhando o roteiro imposto ao público.

No M useu Casa de Cora Coralina, o deslocamento do visitante é controlado, acompanhado por um guia, e obedece a um único roteiro: 0 "Quarto da Cora", a "Sala de Escrita", a "Sala de Condecorações", a "Biblioteca", o "Porão", a "Sala de Vendas", a "Varanda", a "Cozinha" e a "Sal a de M emória da O bra". Em cada ponto do trajeto, o guia rel ata informações específicas, cujo núcl eo se manteve praticamente inal terado desde a inauguração.

Com o intuito de percorrer a Casa de Cora Coralina, vamos "ouvir" a guia M aria José, funcionária da Casa de Cora Coralina há quinze anos, em uma gravação realizada em 20 de agosto de 1999:

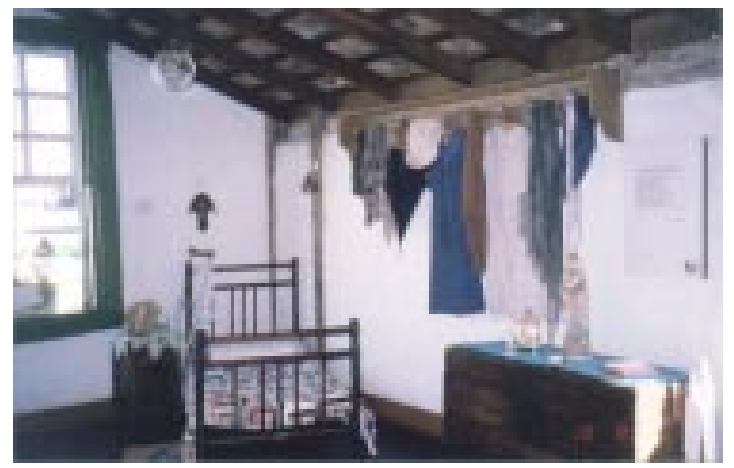

Quarto: Em 20 de agosto de 1889, A na Lins dos Guimarães Peixoto B retas, Cora Coralina, nascia neste quarto. A Cora passou toda a infância nesta casa. Essas são algumas das roupas que pertenceu [sic] a Cora. Essa mul eta Cora usou a partir de 74 , quando ela sofreu uma queda e quebrou o fêmur direito. Cora usou muleta até 0 último dia de vida. 0 baú em couro pertenceu à mãe de Cora, J acintha L uísa do Couto B randão. Eleé de 1881. Couro puro e contém as iniciais em cima. A li atrás, a Cora, com 20 anos. Dois anos depois, em 1911, a Cora casou. Ela casou e teve quatro filhos, 15 netos e 29 bisnetos. Ela morou 45 anos no interior de São Paulo: Avaré, Jaboticabal e Andradina. Viúva e os filhos criados, em 56, Cora voltou a essa casa. Cora faleceu em 10 de abril de 85, com 95 anos, em Goiânia. A gora, nós vamos pra "Sala de Escrita", pra conhecer as obras de Cora.

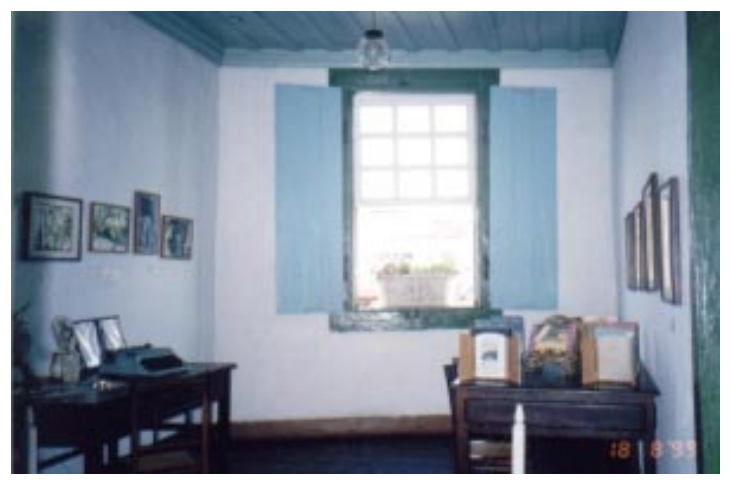

Sala deE scrita: Cora começou a escrever com 14 anos de idade, mas só veio a publicar 0 primeiro livro dela, que é Poemas dos becos de Goiás, com 75 anos. Dez anos depois, foram publicados Meu livro de cordel, Vintém de cobre, que é autobiográfico e, após a morte de Cora, foram publicados H istória da Casa Velha da Ponte, Meninos verdes, que é literatura infantil, Tesouro da Casa Velha e A moeda de ouro que o pato engoliu, que é também literatura infantil. N essa mesa, ela escrevia os poemas ... todos os objetos que a Cora usou. A Cora estudou só até a terceira série primária. 0 único curso que ela fez foi datilografia, aos 75 anos. A os 93 anos el a não conseguia mais dati lografar. 0 "Selo do Centenário"... Dia 20 de agosto é o dia do aniversário de Cora. N esse dia, ela criou o "Dia do Vizinho" e o "Dia do Cozinheiro". 0 "Dia do Vizinho" porque Cora dizia que o vizinho é o parente mais próximo nosso. E o "Dia do Cozinheiro" porque é a pessoa que prepara nossa mesa. A qui na cidade de Goiás é comemorado o dia 20 de agosto. A qui atrás, temos o Troféu Juca Pato que a Cora recebeu da U nião B rasileira de Escritores. Ela éainda a única mulher no $B$ rasil a ter recebido esse troféu. 0 capacete que ela ganhou de um engenheiro do metrô de São Paulo, que esteve na casa fazendo uma visita e deixou como doação. A gora, nós vamos conhecer a "Sala de Condecorações". 


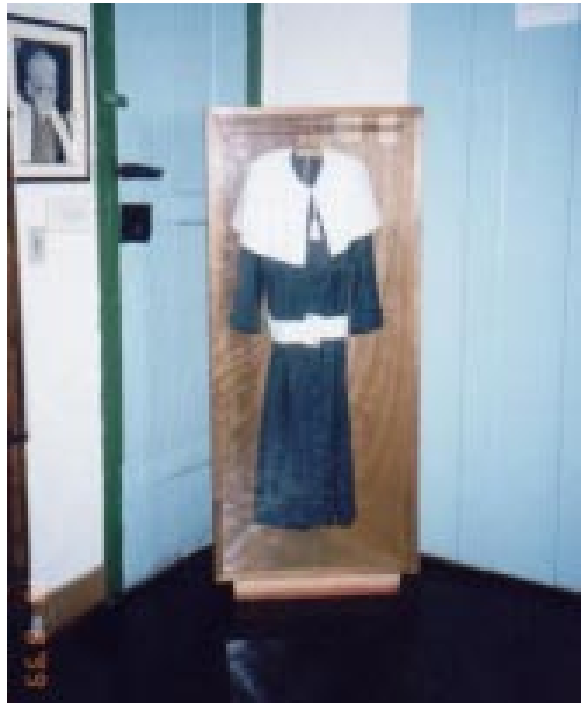

Sala de Condecorações: A beca preta Cora usou quando ela discursou e recebeu o Diploma Honoris Causa da Universidade Federal de Goiás, em 83. A qui, ela com os acadêmicos e com os familiares: filha, nora e genro. A outra beca azul Cora usou quando ela recebeu 0 diploma da A cademia Feminina de L etras e A rtes de Goiás, cadeira número 5. A o lado, a Cora declamando. Vamos conhecer a "Biblioteca", agora.

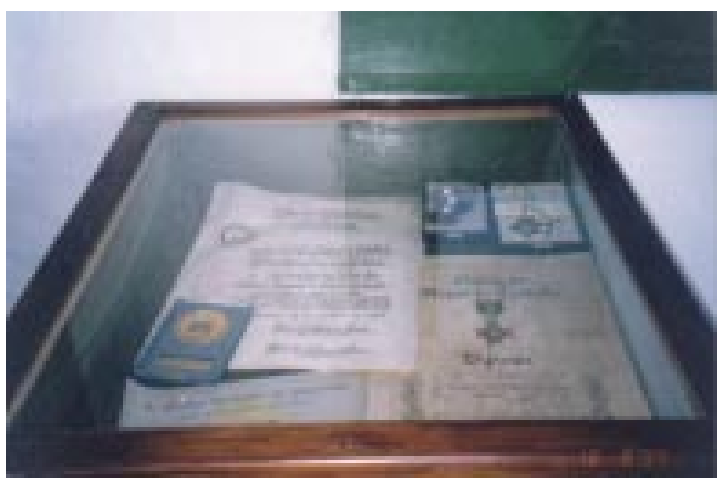

Biblioteca: Essa é a biblioteca de Cora. Tem os diplomas, placas, manuscritos, cartas de Carlos D rummond de A ndrade, J orge A mado, M onteiro L obato, do Vaticano, e os livros que a Cora lia. A Iguns recentes doados para a Casa.

Porão: Essa bica... essa água vem de uma nascente de cima do morro, ela passa por debaixo da I greja do R osário. Ela é uma água potável [sic] e tem desde a construção da casa. Tem mais de duzentos anos essa bica aqui na casa. A li embaixo, os pertences de uma senhora que vinha todas as noites dormir no porão. Ela era conhecida por M aria Grampinho, porque usava mais de 100 grampos na cabeça. Ela faleceu cinco meses depois da Cora.

Sala de Vendas: Essa é uma "Sala de Venda", onde temos os livros de Cora, livros de outros escritores goianos, cartões postais, pôsters, camisetas e trabalhos artesanais feitos pelas pessoas da cidade.

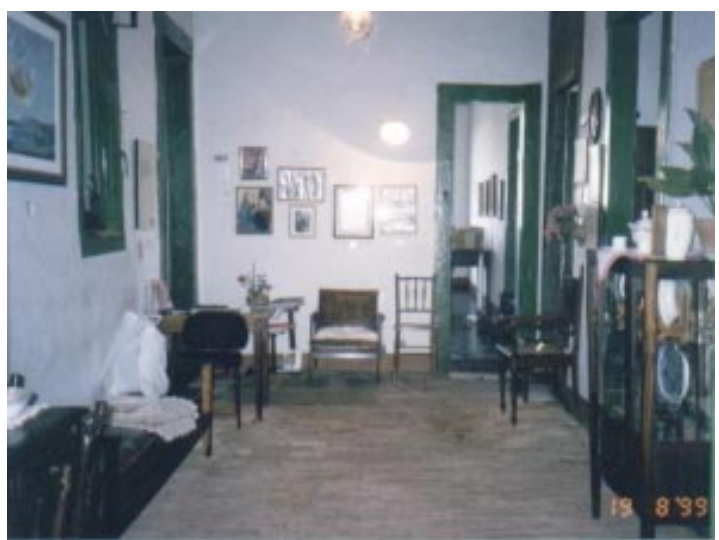

Var anda: Essa é a sal a onde a C ora recebia os turistas, sentada naquela poltrona. A qui, ao lado, nós temos o pai da Cora ... ele está morto nesta fotografia. A Cora não conheceu o pai. Ela tinha 25 dias de nascida quando o pai faleceu. A o lado, o bando de L ampião e Padre Cícero, porque Cora sempre falava que tinha admiração pelo bando de Lampião. 0 pai era paraibano. Esse aqui é o aparelho azulpombinho... que conta o poema e a história desse aparelho está [sic] no primeiro livro da Cora, Poemas dos becos de Goiás. E, agora, nós vamos conhecer a "Cozinha".

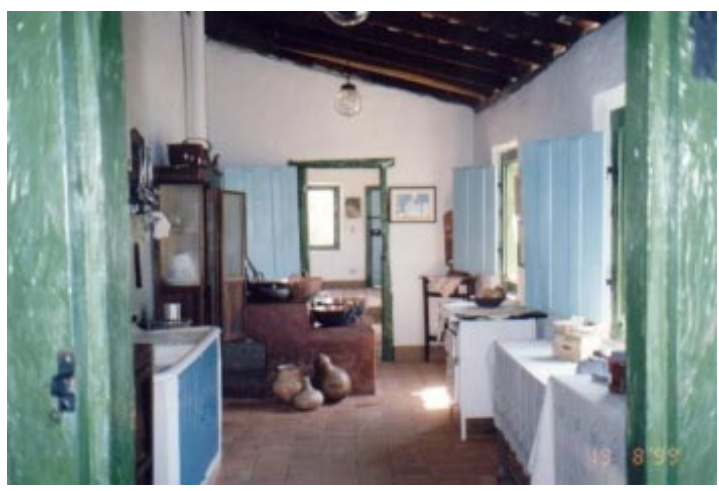

C ozinha: Essa é a cozinha da Cora. A Cora foi doceira durante 14 anos, fazendo doces cristalizados. Hoje, tem quem dá continuidade. Os doces estão à venda. A queles foram os 
tachos usados por Cora ... a geladeira ... todos os objetos da cozinha.

Sala deM emória da Obra: E essa éuma "Sala de M emória da O bra". Faz parte da restauração da casa. Quando a Cora faleceu, a casa tava do jeito que estão [sic] nos quadros. A restauração durou três anos, pra depois ser aberta como museu.

N a composição da exposição museológica, um conjunto de móveis, objetos, fotografias, pinturas e painéis com trechos da produção literária da poeta entrelaça-se ao discurso do guia, construindo uma narrativa biográfica que estabelece os contornos da M ulher-M onumento. Em cada um dos aposentos, determinados marcos biográficos são estabelecidos, de modo a promover um enquadramento da memória (Pollak, 1989) e a produzir uma biografia oficial. A o mesmo tempo, as imagens e os discursos evocam a cidade de Goiás e, mais especificamente, a Casa Velha da Ponte. O u seja, mecanismos de transferência de sentidos atuam para promover a simbiose da poeta com a cidade e instituir a memória individual como representação da memória coletiva.

$\mathrm{Na}$ narrativa delineada ao longo do percurso, "os obj etos são suportes de significações que a própria exposição museológica propõe" (M eneses, 1994, p. 86). No M useu Casa de Cora Coralina, os conteúdos social e historicamente construídos para o gênero feminino em nossa cultura são agenciados continuamente por meio da exibição de um conjunto de artefatos femininos que funcionam como vetores de construção do gênero e de instituição da MulherM onumento.

$\mathrm{Na}$ coleção exposta, encontramos objetos pessoais - roupas, chinelos, valises de viagem, muletas, óculos, leques, canetas - e objetos de trabal ho, como a máquina de costura, a máquina de escrever, a balança e os tachos de cobre. A lém de uma infinidade de objetos domésticos: louças, panelas, utensílios de cozinha, toal has e guardanapos. 0 gênero está incrustado nesses objetos biográficos (B osi, 1987) que nos contam histórias femininas, pois são artefatos de que as mulheres se servem, mantêm e conservam diariamente.
Para os objetos-testemunho do cotidiano de Cora Coralina, os suportes constituem também parte da coleção biográfica: utilizam-se peças de mobiliário e utensílios que compunham os ambientes domésticos da Casa. O u seja, os objetos são contextualizados pela composição museológica do "Quarto", da "Varanda", da "Cozinha", da "Sala de Escrita".

Para além da existência banal de artefatos geral mente produzidos em série, cada um desses objetos, deslocado do universo privado para o espaço público, passa a ser considerado único e singular, "auráticos" na expressão benjaminiana (B enjamin, 1994), exatamente por terem pertencido a Cora Coralina e interligarem-se entre si, formando uma trama narrativa que compõe tanto o cotidiano quanto a imagem pública da poeta.

Os objetos que são as insígnias da consagração da M ulher-M onumento - troféus, diplomas, medal has, condecorações, becas - estão majoritariamente expostos em mobiliário museológico: armários e vitrines, que formam a "Sala de Condecorações" e a "Biblioteca".

Essas estratégias diferentes de contextualização dos objetos, tal como destaca U Ipiano M eneses (1994; 1998), são fundamentais para a construção do ol har do visitante: a composição dos ambientes domésticos desloca a apreensão dos significados dos objetos para a esfera privada, enquanto a "vitrinização" remete à interpretação, em última instância, para os sentidos engendrados no espaço público ao longo do processo de monumentalização da poeta.

$\mathrm{Na}$ casa da memória da Mulher-Monumento, diferentemente do que ocorre em museus construídos em torno de personagens masculinos, os espaços privados da cozinha e do quarto são valorizados e o ambiente feminino é reconstruído com a utilização dos objetos do cotidiano.

$\mathrm{Na}$ "Cozinha", os instrumentos que mol dam a prática culinária de fazer doces são transformados em objetos biográficos emodulam o ofício de doceira como marco da história de vida (Delgado, 2002): o fogão a lenha, os tachos de cobre, a presença das frutas da região, a bal ança e os próprios doces à venda reinventam a prática de fazer doces. Com essas peças singularizadas pelas marcas deixadas pelo fazer cotidiano, 
reconstruímos os gestos e as vivências daquela que os mani pulou, investindo-as de intenso valor simbólico. Sacral izados pelo ambiente museológico, os doces tornam-se alimentos-signo da tradicional arte da doçaria, constituindo apelo irresistível para o turista.

$N$ esse espaço socialmente considerado como domínio feminino, o tempo acumula-se no mobiliário e nos utensílios, tecendo víncul os entre um passado muito antigo e o presente fugidio do trabal ho cotidiano das mul heres. N os painéis ali expostos, o discurso literário da poeta é agenciado na construção dos sentidos para a exposição:

\author{
M inhas mãos doceiras \\ J amais ociosas, \\ Fecundas. Imensas e ocupadas. \\ $M$ ãos laboriosas. \\ A bertas sempre para dar, \\ ajudar, unir e abençoar. \\ [...] (In: M eu livro de cordel)
}

A pobreza em toda a volta, a luta obscura de todas mulheres goianas. No pilão, no tacho, fundindo velas de sebo, no ferro de brasas de engomar. A ceso sempre o forno de barro.

As quitandas de salvação, carreadas pelos tabuleiros, os abençoados vinténs, tão valedores, indispensáveis.

E ram as costuras trabal hadas, os desfiados, os crivos pacientes. A reforma do velho, o aproveitamentos dos retalhos.

Os bordados caprichados, os remendos instituídos, os cerzidos pacientes ...

Tudo economizado, aproveitado. Tudo ajudava a pobreza daquela classe média, coagida, forçada a manter as aparências de decência, compostura, preconceito, sustentáculos da pobreza di sfarçada. Classe média de após treze (13) de maio. Geração ponte, eu fui, posso contar.

Cora Coralina

$\mathrm{N}$ essas duas poesias, assim como em toda sua obra, Cora Coralina engendra, em um duplo movimento de escrita da memória, o passado coletivo e o individual: "M oinho do tempo" (Coralina, 1984), poesia memorialista, revela a pobreza do passado configurada na labuta cotidiana das mulheres goianas; "Estas M ãos" (Coralina, 1994), autobiográfica, recria o traba-
Iho como marco biográfico com base nas marcas inscritas no próprio corpo. Entrelaçadas com a linguagem espaço-temporal do discurso museológico que nos desloca para as antigas cozinhas goianas, as poesias falam do trabalho das mulheres, aproximando-nos do conjunto de gestos, códigos, saberes femininos envolvidos na execução dos afazeres domésticos que se desdobravam em ofícios femininos para a obtenção dos "abençoados vinténs, tão val edores, tão indispensáveis".

O "Q uarto", espaço doméstico que costuma ser ocultado aos ol hares estranhos, é composto museograficamente de forma a recompor a intimidade feminina. Significativamente, é o primeiro aposento do roteiro estabelecido para o visitante, constituindo o lugar escol hido para o discurso museológico estabelecer os fatos fundamentais da trajetória de vida de Cora Coralina.

0 perfil biográfico traçado pelo guia é pontuado pelas grandes datas de uma vida - 0 nascimento, em 1889; o casamento, em 1911; a transferência para São Paulo; o retorno para Goiás, em 1956, e o falecimento, em 1985. A intersecção do tempo cronológico com o tempo social instaura os conteúdos culturais da identidade feminina, apoiando-se em ciclos: infância, juventude, casamento, maternidade, viuvez, velhice. A travessando as referências temporais, o espaço emerge como núcleo: a Casa Velha da Ponteéo centro simbólico, espaço existencial e sagrado (B achelard, 1993), que funda o mundo de Cora Coralina - é o centro do seu destino, onde ela nasceu, passou a infância e a juventude. D esse lugar ela partiu para viver o casamento e a maternidade, retornando na vel hice para tecer a imortal idade.

De forma mais intensa que nos outros ambientes, no "Quarto", as marcas que o uso imprimiu aos objetos biográficos recordam mais do que a passagem do tempo, pois constituem vestígios materiais que ganham significado ao incorporar a interação com o corpo que os manipulou em práticas cotidianas rotineiras: os chinelos furados, o leque gasto, o castiçal quebrado, as muletas rotas que apoiaram o corpo cansado, a fronha furada que tantas vezes guardou o sono da poeta evocam a presença de Cora Coralina, seu toque e seus gestos. 
N esse lugar privilegiado da vida íntima, as peças do vestuário da poeta formam um conjunto de objetos que são vetores da subjetividade feminina (Perrot, 1989) e tornam-se estratégicos para a construção da narrativa de cunho autobiográfico. Diferentes composições são realizadas com os vestidos simples, a maioria de uso doméstico, combinados ao chapéu, ao guarda-chuva e aos diferentes lenços, echarpes, chal es e bolsas. Inseridos na exposição museológica, esses el ementos representam a dimensão privada da vida feminina e mobilizam o desejo do espectador de apreender a intimidade que essas roupas denotaram outrora.

O utra prática feminina no trabalho com 0 passado é a materialização da memória familiar em artefatos cuidadosamente preservados, alguns guardados e outros exibidos ao ol har público (B arros, 1989). Essa estratégia de memória do espaço doméstico é apropriada pelo museu, e a "Varanda" é o lugar privilegiado da memória familiar, recriada por Cora nos seus livros. D entro da cristal eira, por exemplo, encontram-se cacos das peças que compunham um aparelho de jantar que foi âncora da memória nas poesias "Estória do aparel ho azul-pombinho" e "O prato azul-pombinho", do livro Poemas dos becos de Goiás e Estórias mais (Coralina, 1993), nas quais a poeta traça um painel dos costumes e dos rituais das famílias goianas tradicionais. Os objetos expostos nesse aposento configuram signos da genealogia, que evidenciam e destacam a importância da linhagem e o papel das relações de parentesco na construção biográfica da M ulher-M onumento.

A o longo da análise dos espaços domésticos reconstituídos, percebe-se que o gênero atribui significados à exposição museológica, configurando uma narrativa material engendrada por móveis e objetos biográficos pessoais e familiares que falam do cotidiano, dos afetos e das práticas da M ulher-M onumento.

Outro importante componente da coleção biográfica é o conjunto de imagens da poeta espal hadas pela C asa, distribuídas em múltiplos suportes: fotografias, quadros, objetos. Com exceção de duas fotografias da década de 1920, que estão no "Quarto", a iconografia retrata a poeta na velhice. 0 acervo museológico reproduz, com isso, a personagem da anciã doceira e poeta construída pela mídia, na década de 1970 e, principalmente, no início da década de 1980.

No processo de monumentalização, essas imagens-símbolo são evocadas recorrentemente, pois a produção, a circulação e a recepção dos discursos de Cora Coralina são indissociáveis da figura humana: a vel hinha de cabel os brancos, magra, face enrugada, de aparência frágil, locomovendo-se com dificuldade, encantava quando transformava a voz trêmula em um torrencial de palavras fortes. A ancianidade constitui, portanto, peça fundamental na teia discursiva que institui a poeta como M onumento, socialmente investida do poder de recordar, testemunhar e eternizar o passado.

A inscrição de Cora Coralina como arquivista e arauto da memória constitui matéria primordial da narrativa museológica, na qual objetos, imagens e poesias vão urdindo uma trama com os fios entremeados do passado individual, familiar e coletivo, construindo 0 poder de evocação da M ulher-M onumento.

Nesse processo, a memória de Cora Coralina é amal gamada com a Casa Vel ha da Ponte, em uma prática estratégica para cel ebrar, comemorar e perpetuar a poeta como monumento da cidade de G oiás. 0 discurso material, 0 iconográfico e o literário engendram o espaço da Casa Velha da Ponte como síntese de todos os tempos da cidade, tal como está sintetizado na "Sala de M emória da Obra", e a Mulher-M onumento como artesã e guardiã dessa memória ancestral.

A exposição da Casa de Cora Coralina expressa o princípio orientador da biografia institucionalizada: a narrativa museológica é a solidificação da autobiografia produzida por Cora Coralina, na qual presente e passado são construídos, entrelaçando os tempos da vida à cidade de Goiás. Podemos, portanto, afirmar que tal concepção museológica pretende construir a memória individual como símbolo da memória da cidade, consagrando e imortal izando a CoraM onumento.

A narrativa biográfica do museu no confronto da batalha das memórias

No processo de consagração da imortal, duas construções póstumas lutam pela produção, pelo controle e pela divulgação da biografia 
oficial da Mulher-M onumento: a narrativa biográfica do M useu Casa de Cora Coralina, que reproduz a autobiografia tecida pela poeta na sua obra e nos seus depoimentos, confrontase com a biografia Cora coragem, Cora poesia, escrita pela filha caçula Vicência B rêtas Tahan, que esmiúça acontecimentos não revelados publicamente por Cora Coralina e provoca a ruptura com a memória de si instituída pela literata.

E ssas estratégias divergentes que se digladiam para a construção da M ulher-M onumento contrapõem-se com a memória dissidente engendrada por uma parcela dos moradores e moradoras de Goiás que contestam a monumentalização da poeta.

Para analisar essa batalha das memórias, vamos perscrutar os mecanismos de construção, divulgação e preservação de uma memória subterrânea na cidade de Goiás.

Durante as entrevistas com os vilaboenses - como são conhecidos aqueles que nascem e/ ou moram na cidade de Goiás, perpetuando a referência à denominação anterior de Vila B oa -, quando eu solicitava que conversássemos a respeito de Cora Coralina, muitos depoentes mudavam o tom da narrativa, alguns pediram para desligar o gravador em muitas passagens e outros solicitaram a interrupção da entrevista, alegando temer represálias. Foi necessário prescindir de informações importantes para caracterizar a fonte e assegurar que não utilizaria qual quer parâmetro de identificação, como nome, profissão ou idade. Essa atitude de temer gravar depoimentos, mesmo depois de ter conversado informalmente com a pesquisadora sobre 0 assunto, denota a eficiência dos mecanismos de silenciamento dos discursos dissidentes.

A memória subterrânea, na acepção de Michel Pollack, opõem-se à memória instituída como oficial e "prossegue seu trabalho de subversão no silêncio" $(1989$, p. 4). Os conflitos e a competição entre a biografia oficial izada pel a Casa de Cora Coralina que cria a MulherM onumento e a memória que produz a Cora estigmatizada são ininterruptos na cidade de Goiás. A preservação dessa memória divergente está interligada a uma rede de sociabilidade, unindo grupos de moradores que, na maior parte dos casos, convivem desde a infância, encontram-se quase diariamente e guardam um repertório de histórias que são relembradas constantemente.

Na memória subterrânea, os significados e sentidos da vida de Cora Coralina, ou A ninha/ A nica como era chamada na juventude, estão concentrados ou cifrados em um momento crucial, contado com el ementos invariáveis:

"Todo mundo sabe que Cora fugiu com um homem casado, viveu com um homem sem ser casada, acho que nunca casou mesmo", afirma uma depoente. 0 utro repete: "Todo mundo sabe que Cora saiu fugida, montada num burro, na garupa de um burro, com um homem casado. $E$ foi lá para São Paulo."

"Foi quando ela deu aquele passo de escandalizar uma sociedade fechada como a nossa", analisa uma depoente, "vovó é que contava para mamãe. [...] 0 povo antigo da cidade não esqueceu, todo mundo conhece esse histórico de vida dela, que eu acho que foi um determinismo de vida."

A ssevera um morador: "N ossa cidade tem o escol da cultura goiana, e o povo sabe posicionar-se nos seus moldes morais. Como estimar um mulher que todo mundo sabe que montou na garupa de não sei quem, um homem de fora, que era casado e foi embora?"

Uma parente de Cora considera que essa história macul ou também os familiares:

Quando A nica namorou com um homem casado, ela não contou nem para mamãe que era íntima dela, mamãe não sabia de nada. Foi uma mágoa muito grande, todos da família ficaram mal com aquilo. A mãe dela ficou doente, envergonhada de Cora ter feito aquilo. A mãe dela ficou sem sair na rua muito tempo, ficou trancada em casa.

Poderíamos "ouvir" essa história contada por mais pessoas, porém, os padrões da narrativa e o enredo continuariam os mesmos: a noite em que A ninha/Cora fugiu de Goiás com um homem casado, em um lombo de burro. A identidade do homem interessa muito pouco, sua condição de casado é que constitui 0 aspecto fundamental desse enredo resumido.

A maneira sintética como 0 acontecimento é narrado encerra seu significado, pois a reve- 
lação de um só momento, de uma única cena, de um único ato converte-se no resumo biográfico com base no qual instituem o estigma que marca Cora Coralina e pela qual sua imagem é construída por parte da memória subterrânea. Os depoentes consideram desnecessário acrescentar outros elementos além da fuga de uma jovem com um homem casado, pois aí se condensa o valor emblemático da transgressão feminina.

Em poesias e depoimentos, entretanto, Cora Coralina imprimiu uma versão para sua vida que corresponde ao destino que ela aprendeu a atribuir ao gênero feminino, contando sobre o noivado, o casamento em 1910 e a mudança para São Paulo em 1911, citando as respectivas datas dos eventos tal qual ocorre no resumo biográfico apresentado no M useu Casa de Cora Coral ina durante a visita ao "Q uarto".

Esse episódio da fuga para São Paulo, silenciado e/ou ocultado pela poeta e pela narrativa museológica, torna-se o ponto central da composição da narrativa biográfica do livro Cora coragem, Cora poesia (Tahan, 1989), que esmiúça o romance entre Cora Coralina e Cantídio B retas: a aproximação entre os dois; 0 namoro com o consentimento da família; a decisão materna de proibir o relacionamento depois da descoberta que Cantídio havia abandonado a esposa e os três filhos em São Paulo, além de ter uma filha com outra mulher; os encontros de Cora e Cantídio às escondidas e a gravidez; a decisão de passar a viver com Cantídio, rejeitada pela mãe de Cora; o planejamento e os detalhes que marcaram a fuga empreendida pelo casal na madrugada do dia 25 de novembro de 1911.

A o tornar este o fato central do livro, a autora propôs-se a contar um segredo guardado por sua mãe, algo desconhecido, um ponto obscuro da sua vida privada. Com essa estratégia, Vicência procura estabelecer um pacto com os leitores baseado naquilo que Janet $\mathrm{M}$ alcom chama de "natureza transgressiva da biografia":

a incrível tolerância do leitor (que não se estenderia a um romance mal escrito como a maior parte das biografias) só faz sentido se for entendida como uma espécie de cumpli- cidade entre ele e o biógrafo numa atividade excitante e proibida: atravessar o corredor na ponta dos pés, parar diante da porta do quarto e espiar pelo buraco da fechadura. ( $M$ alcon, 1995, p. 17)

A história romântica narrada por Vicência, que termina por exaltar a coragem e a determinação de A na/Cora em enfrentar os preconceitos da época, adquire outros sentidos na memória subterrânea, configurando um estigma, na acepção de Erving G offmann (1975), uma marca socialmente instituída, que configura uma mácula no status moral e determina práticas de exclusão do indivíduo.

Quando a poeta retorna para a cidade de Goiás, as quatro décadas de ausência não tinham apagado a lembrança desse episódio e ela reencontra-se com a história da fuga da jovem A ninha, transmitida de geração para geração. Conforme resume um depoente, "essa história ficou na cidade, essas coisas o povo não esquece não".

0 conjunto de histórias, com as quais uma parcela dos moradores compõe a memória dos anos em que a poeta morou na Casa Velha da Ponte, faz sentido à medida que se relaciona com o mesmo momento crucial e simbólico que funda uma identidade. A mecânica da estigmatização estabelece-se nas relações sociais e associa valores e conceitos depreciativos aos atos e à personalidade de Cora Coralina.

A memória subterrânea é composta por um conjunto de lembranças dissidentes da imagem oficial, transmitidas e preservadas nas redes familiares e de amizades. Tanto que el as foram expressas com mais facilidade em entrevistas coletivas, nas quais as pessoas recorriam umas às outras para referendar o que estavam contando, encadeando histórias que fazem parte de um repertório comum, demonstrando que foram muitas vezes recordadas pelo grupo. Há muito tempo, histórias a respeito de Cora Coralina mantêm girando, como diria N orbert Elias e J onh Scotson (2000, p. 92), as rodas do moinho da fofoca na cidade de Goiás.

A utilização do termo "fofoca" não desvaIoriza nem questiona o discurso dos depoentes, mas explicita uma rede de comunicação que tem importante função na dinâmica social da cidade 
de Goiás e que constitui um instrumento de poder. Para nossa investigação, interessa que esses discursos têm a força de construir uma biografia e delinear uma personalidade para a poeta, digladiando-se com a biografia oficial instituída pela Casa de Cora Coralina.

0 relacionamento conflituoso que a poeta estabelecia com os moradores da cidade é substrato de muitos acontecimentos narrados. Como conta uma vilaboense, "Cora era grosseira com o povo de Goiás, ela era bem grosseira. 0 povo de fora ela tratava muito bem, mas 0 povo de Goiás, não, conosco não".

Outra moradora assegura que "Cora não tinha absolutamente nenhum respeito pelo povo da cidade, inclusive com os parentes dela, ela não se dava com nenhum parente", evocando as contendas em torno do inventário da Casa Velha da Ponte.

"Ela tratava muito bem o turista, agora, quando era uma pessoa daqui, ela era mais áspera", afirma outra vilaboense. Esse aspecto foi recorrente em vários depoimentos, alguns enfatizados com a afirmação que a doceirapoeta não gostava de fazer doces para os moradores de Goiás, pois só se interessava em vendêlos aos turistas. Essas pessoas estabelecem, assim, um contraponto entre o tratamento que Cora dispensava ao turista e o modo como se relacionava com os moradores da cidade.

V árias histórias são contadas para confirmar a idéia de que Cora não "tinha educação, amabilidade, não sabia receber em sua casa", confrontando seu comportamento "rude, às vezes hostil" à hospital idade que caracteriza os vilaboenses e analisando-o com base em padrões que as depoentes acreditam compor os códigos femininos de receber e fazer visitas.

U ma depoente sintetizou a interpretação subjacente aos relatos: "Ela ficou fora da cidade e então não tinha uma mentalidade muito goiana. [...] na realidade, o povo goiano não se dá muito com o jeito dela. Ela era independente, ela se acostumou na vida de São Paulo, naquele temperamento". Essa "independência" configura-se no fato de Cora viver sozinha na Casa Velha da Ponte, afastada da família e com poucos amigos, interpretado como rompimento com os "Iaços sagrados da família" e com a rede de sociabilidade construída na cidade.
M uitos repetem: "Cora nunca se integrou na cidade". Ou seja, ao mesmo tempo que os relatos mostram como a Cora estigmatizada é excluída do convívio da "boa sociedade" - como definiu uma moradora - , também a censuram por essa não-participação.

Enquanto alguns depoentes estabelecem uma interpretação depreciativa para a obra da poeta, valorizada pela biografia oficial, outros tratam de questionar o ofício de doceira, marco da monumentalização.

Quando realizei uma pesquisa acerca das doceiras da cidade (1999), ao entrevistar uma senhora muito idosa, ela conta, espontaneamente, a história da fuga e afirma que Cora não fazia doces, que ela comprava das outras doceiras para vender aos turistas. Ela enfatiza que começou a fazer doces, "muito antes dessa Cora Coral ina", eexclama: "I magina, uma mulher que fugiu com um homem casado!". Outra doceira questionou a fama de Cora, colocando uma série de defeitos nos doces que ela preparava. No entanto, nesse mesmo conjunto de depoimentos, duas doceiras destacam que só começaram a fazer doces depois que Cora Coralina tornou o ofício reconhecido e transformou-o em trabal ho rendoso em razão do atrativo que exerce sobre 0 turista.

As narrativas que menosprezam os doces da poeta, ou mesmo rejeitam a idéia de que ela os fizesse, demonstram que um dos mecanismos da memória subterrânea é a criação de uma imagem, para a mulher que desrespeita as normas de conduta esperadas para 0 gênero feminino, diametralmente oposta à identidade positiva que as mulheres depoentes têm de si mesmas. Ou seja, essas doceiras recusam-se a compartilhar o ofício com uma mul her que elas denigrem moral mente.

Conforme Elias também percebeu na comunidade que investigou, "os mexericos de censura apelavam mais diretamente para 0 sentimento de retidão e de virtude daqueles que os transmitiam". A o construir a Cora estigmatizada, homens e mulheres "reforçam a comunhão dos virtuosos. 0 fato de mexericar com os outros sobre tal assunto era prova da própria irrepreensibilidade" (Elias e Scotson, 2000, p. 124), pois a censura grupal imposta aos que infringem as regras tem uma vigorosa função integradora. 
É preciso destacar, no entanto, que a monumentalização da poeta é reconhecida mesmo por esses depoentes que discordam do processo e produzem os marcos da memória subterrânea. Questionar a biografia hegemônica não significa, porém, negar que o "mito" ou o "fenômeno" Cora Coralina, como se referiram alguns depoentes, é a principal atração da cidade e que o museu, que guarda sua memória, é o local mais visitado pelos turistas. Comentando a hegemonia da memória oficial, uma vilaboense desabafa: "O mito Corajá é muito forte, e a gente não vai derrubar mesmo".

Tanto a prática autobiográfica de Cora Coralina quanto as produções discursivas que instituem a imortal ganham novos contornos quando consideramos esse campo de conflitos configurado em Goiás e que constitui o palco principal onde desenrolam-se as lutas dessa batal ha das memórias.

A lembrança e o esquecimento, como mecanismos indissociáveis da memória, são faces do processo de monumentalização: 0 passado é manipulado para escul pir as lembranças que perpetuam os contornos da MulherM onumento, ao mesmo tempo que estratégias de poder urdem o esquecimento configurado no silêncio, na omissão e no ocultamento das memórias dissidentes que, entretanto, mantêmse latentes na cidade de G oiás.

Abstract: The contest by the fabrication of cora Coralina's biography involves a memory network which support, cross and exclude themselves: the autobiography weaved by the poetess, the biographical memory written by her daughter - V icência Brêtas Tahan, the under ground memory engendered in Goias city. In this conflicting field, I intend to investigate the building work and the memory management promoted by museological biographical speech. In the Cora Coralina's House Museum, the arrangement, context and space-time configuration of its fumiture, dbjects, photography and poetries build up the poetess' s biography in symbiosis with the city memory and they represent the project of promoting her imortalisation as W oman-Monument of Goias.

K ey words: museum; memory; gender.
Referências

ABREU, R egina. Emblemas da nacionalidade: o culto a Euclides da Cunha. Revista Brasileira de Ciências Sociais. São Paulo, n. 24, p. 66-84, 1994.

A fabricação do imortal: memória, história e estratégias. Rio de Janeiro: R occo, 1996.

BA CHELARD, Gaston. A poética do espaço. São Paulo: M artins Fontes, 1993.

BARROS, M yriam Moraes Lins de. Memória e família. Estudos Históricos. Rio de J aneiro, v. 2, n. 3, p. 29-42, 1989.

BENJAMIN, Walter. Magia e técnica, arte e política. São Paulo: Brasiliense, 1994.

BOSI, Ecléia. M emória e sociedade, lembranças de velhos. São Paulo: T. A. Queiroz, 1987.

COELHO, Gustavo Neiva. Guia dos bens imóveis tombados em Goiás. Goiânia: Instituto de A rquitetos do B rasil, 1999.

CORALINA, Cora. Estórias da Casa Velha da Ponte. São Paulo: Global, 1986.

. M eu livro de cordel. São Paulo: G lobal, 1994. $\overline{1996 .}$

. 0 tesouro da Casa Velha. São Paulo: Global,

Poemas dos becos de G oiás e estórias mais. São Paulo: Global, 1993.

Vintém de cobre - meias confissões de A ninhna. Goiânia: Editora da U niversidade Federal deGoiás, 1984.

DELGA DO, A ndréa Ferreira. M emória, trabalho e identidade: as doceiras da Cidade de Goiás. Cadernos Pagu. Campinas, n. 13, p. 293-325, 1999.

A invenção de Cora Coralina na batalha das memórias. Campinas, 2003. Tese (D outorado) Programa de Pós-Graduação em História, U niversidade Estadual de Campinas.

Cora Coralina: a poética do sabor. Ilha. Revista de Antropologia. Florianópolis, v. 4, n. 1, p. 59-83, 2002.

ELIAS, N orberteSCOTSON, J onh. O s estabel ecidos e os outsiders: sociologia das relações de poder a partir de uma pequena comunidade. Rio de J aneiro: Jorge Zahar, 2000.

FOUCA ULT, M ichel. Des espaces autres. Dits et écrits. Paris: Éditions Gallimard, 1994, v. IV.

GOFFMANN, Erving. Estigma, nota sobre a manipulação da identidade deteriorada. Rio de J aneiro: Zahar, 1975.

GOMES, Angela. A guardiã da memória. Acervo: Revista do Arquivo Nacional. Rio de J aneiro, v. 26, p. 17-30, 1997. 
M A LCON, J anet. A mulher calada: Silvia Plath, e os limites da biografia. São Paulo: Companhia das Letras, 1995.

MENESES, U Ipiano T. Bezerra de. Do teatro da memória ao laboratório da História: a exposição museológica e o conhecimento histórico. Anais do M useu Paulista, N ova Série, São Paulo, v. 2, p. 9-42, 1994.

. Memória e cultura material: documentos pessoais no espaço público. Estudos H istóricos. Rio deJ aneiro, v. 11, p. 89-103, 1998.

NORA, Pierre. Entrememórias e história. A problemática dos lugares. Projeto H istória. São Paulo, n. 10, p. 8-28, 1993.

ORTIZ, Renato. Cultura brasileira \& identidade nacional. São Paulo: Brasilense, 1985.
PERROT, M ichelle. Práticas da memória feminina. Revista Brasileira de H istória, São Paulo, n. 18, p. 9-18, 1989.

POLLAK, Michel. Memória e identidade social. Estudos Históricos, Rio deJ aneiro, v. 5, n. 10, p. 200212, 1992.

. M emória, esquecimento, silêncio. Estudos Históricos. Rio de J aneiro, v. 2, n. 3, p. 3-15, 1989.

TA HA N, Vicência. Cora coragem, Cora poesia. São Paulo: Global, 1995.

TELLES, José. No santuário de Cora Coralina. Goiânia: Editora do A utor, 1991.

VELLASCO, M arlene Gomes de. A poética da reminiscência. Estudos sobre Cora Coralina. Goiânia, 1999. Dissertação (M estrado) - Instituto de Ciências H umanas e Letras da U niversidade F ederal de Goiás. 